\title{
Trees description in the main square of São José do Rio Preto, São Paulo State, Brazil ${ }^{(1)}$
}

\author{
CAMILA JUNQUEIRA FERNANDES(2), MARCOS VIEIRA FERRAZ(2)*, RENATA GIMENES(2), \\ SUZANA TARGANSKI SAJOVIC PEREIRA(2), KATHIA FERNANDES LOPES PIVETTA ${ }^{(2)}$
}

\begin{abstract}
The knowledge of the flora existing in the cities is of great importance from the ecological and sustainable point of view, as well as being a premise for actions that provide greater safety, comfort and well-being for the population. The objective of this work was to perform an analysis of the composition, diversity and quality of the tree flora (trees and palms) existing in Rui Barbosa Square, São José do Rio Preto, São Paulo State. This square is considered the main place for its location, history and use, and is located in the central region, next to the Cathedral. The arboreal individuals present in the square were counted, identified and evaluated the height and circumference of the trunk at the height of the chest; were determined phytosociological descriptors, Shannon-Weaver index and observed qualitative aspects (stem-glass balance, general status of the specimen, phytosanity and presence of association with other organisms: insects, lichens, epiphytes or parasites). The floristic composition of Rui Barbosa Square, consisted of 15 botanical families, composed of 25 genera and 28 species, in a total of 103 individuals, among trees and palm trees. The most representative species was Dypsis lutescens, with a frequency of $20.39 \%$. The Shannon-Weaver index, an indicator of diversity, was 2.77 , showing that the square presents great floristic diversity. The majority $(72.8 \%)$ of individuals is in a regular or poor state; $66.02 \%$ had some fungus symptoms; $12.62 \%$ present problems due to termite attack; mosses, lichens and epiphytes are present in $73.78 \%$ of the individuals in the square.
\end{abstract}

Keywords: urban trees, public squares, urban planning.

\section{RESUMO}

Caracterização arbórea da principal Praça de São José do Rio Preto-SP, Brasil

O conhecimento da flora existente nas cidades é de grande importância do ponto de vista ecológico e sustentável, assim como ser premissa para ações que proporcionem maior segurança, conforto e bem-estar para população. O objetivo desse trabalho foi realizar uma análise da composição, diversidade e qualidade da flora arbórea (árvores e palmeiras) existente na Praça Rui Barbosa, de São José do Rio Preto, SP. Esta praça é considerada a principal pela localização, história e uso, e encontra-se na região central, ao lado da Catedral. Os indivíduos arbóreos presentes na praça foram inventariados, identificados e avaliados a altura e circunferência do tronco à altura do peito; foram determinados descritores fitossociológicos, índice de Shannon-Weaver e observados aspectos qualitativos (equilíbrio copa-tronco, estado geral do exemplar, fitossanidade e presença de associação com outros organismos: insetos, liquens, epífitas ou parasitas). A composição florística da Praça Rui Barbosa, de São José do Rio Preto, SP, constitui-se de 15 famílias botânicas, composta por 25 gêneros e 28 espécies, num total de 103 indivíduos, entre árvores e palmeiras. A espécie de maior representatividade foi Dypsis lutescens, com frequência de 20,39\%. O índice de Shannon-Weaver, indicador de diversidade, foi de 2,77 , mostrando que a praça apresenta grande diversidade florística. A maioria $(72,8 \%)$ dos indivíduos encontra-se em estado regular ou péssimo; 66,02\% apresentaram algum sintoma de fungo; $12,62 \%$ apresentam problemas decorrentes do ataque de cupins; musgos, liquens e epífitas estão presentes em 73,78 \% dos indivíduos da praça.

Palavras-chave: arborização urbana, praças públicas, planejamento urbano, paisagismo.

\section{INTRODUCTION}

Green areas in cities are important because they have great benefits in the quality of life, by creating recreation environments, by improving air quality, reducing noise pollution and regulating the microclimate, mitigating the occurrence of heat islands (BOLUND and HUNHAMMAR, 1999; SHAMS, 2009; GONÇALVES, 2017).
The knowledge of the urban flora is part of a program of studies that every city should be concerned with developing, aiming at a plan of afforestation that values the landscape and ecological aspects with the use, mainly, of native species. Besides the benefits that directly influence the life of the man, from the ecological point of view, the urban afforestation is fundamental; through it, one can safeguard the biological identity of the region by preserving

DOI: http://dx.doi.org/10.14295/oh.v24i4.1151

${ }^{(1)}$ Received in 05/02/2018 and accepted in 10/07/2018

(2)Faculdade de Ciências Agrárias e Veterinárias, Universidade Estadual Paulista, Departamento de Produção Vegetal, Jaboticabal, SP, Brasil.

*Corresponding author: ferrazmarcos@yahoo.com.br

Licensed by CC BY 4.0 
or cultivating the plant species that occur in each specific region (KRAMER and KRUPEK, 2012).

Natural vegetation has been extensively studied, however, there are few studies on urban flora. Although the phytosociological survey is used in natural communities, the use of phytosociological descriptors in the urban environment can help the understanding and management of these areas and to draw up bigger guidelines aiming at sustainable plans, such as the increase of biodiversity and the creation of green corridors.

In the phytosociological surveys, so-called richness or variety indexes, such as Shannon-Weaver, are indicators of diversity useful in the analysis, and can be used in management decisions and master plans of afforestation in the urban environment (SILVA FILHO and BORTOLETO, 2005).

The rich and diverse landscape of a space destined for the great circulation of people is a guarantee of an environment where there are ecological, social and economic benefits (RODERJAN and BARDDAL, 1998).

The objective of this work was to perform an analysis of the composition, diversity and quality of the arboreal flora of Rui Barbosa Square, São José do Rio Preto, São Paulo, Brazil.

\section{MATERIAL AND METHODS}

The study was carried out in Rui Barbosa Square, which has an area of $5,303 \mathrm{~m}^{2}$, located in the center of the city of São José do Rio Preto, São Paulo State, Brazil, having as reference, $20^{\circ} 48^{\prime} 67^{\prime}$ ' south latitude and $4^{\circ} 22^{\prime} 80^{\prime \prime}$ west longitude. Its population was estimated in 438,354 inhabitants in 2014, in an area of 431,963 square kilometers (IBGE, 2015). The climate of São José do Rio Preto is characterized by seasonality in the rainfall regime, presenting dry winter and rainy summer and according to the classification of Köppen, is classified as Aw, being tropical climate with summer rains (EMBRAPA, 2015).

The inventory was carried out in the first half of 2015 . The number of individuals per species including the tall palm trees was quantified and, in order to facilitate the presentation of the data, were also called "trees". The identification of the species in the field was carried out with the aid of literature (LORENZI et al., 1996; APG, 1998; LORENZI et al., 2003; SOUZA and LORENZI, 2005; LORENZI, 2008; LORENZI, 2009; LORENZI et al., 2010).

For all arboreal individuals, the total height of the plant was evaluated using a Höhenmesser hypsometer, model BL7 and circumference at chest height $(\mathrm{CCH})$, measured at
$1.30 \mathrm{~m}$ from the soil, using a trena and later conversion in diameter at breast height (DBH).

The phytosociological descriptors were calculated according to Rodrigues (1988):

a) Absolute Density ADs (specimen $\mathrm{m}^{-2}$ ): $\mathrm{ADs}=\mathrm{Ns} \mathrm{x}$ $\left(\mathrm{U} \mathrm{A}^{-1}\right)$; on what: Ns = specimen number per species $\mathrm{s}$; $\mathrm{U}$ $=$ sample unit $\left(1 \mathrm{ha}=10.000 \mathrm{~m}^{2}\right)$; e $\mathrm{A}=$ total area sampled $\left(\mathrm{m}^{2}\right)$.

b) Relative density RDs (\%): $\mathrm{RDs}=100 \times\left(\mathrm{Ni} \mathrm{Nt}^{-1}\right)$; on what: $\mathrm{Ni}=$ specimen number per species $\mathrm{s}$; e $\mathrm{Nt}=$ total number of specimen.

c) Basal area of the specie BAs $\left(\mathrm{cm}^{2}\right)$ : $\mathrm{BAs}=\sum \mathrm{P}^{2} / 4 \pi$; on what: $\mathrm{P}=$ perimeter $(\mathrm{cm})$.

d) Absolute Dominance of the species DoAi (\%): DoAi $=\sum \mathrm{ABi} \times(\mathrm{U} / \mathrm{A})$; on what: $\mathrm{ABi}=$ individual basal area of species $\mathrm{i}\left(\mathrm{cm}^{2}\right)$; $\mathrm{U}=$ sample unit $(1 \mathrm{ha})$; e $\mathrm{A}=$ total area sampled $\left(\mathrm{m}^{2}\right)$.

e) Relative Species Dominance DoRi (\%): DoRs $=100$ $\mathrm{x}(\mathrm{SABs} / \mathrm{ABT})$; on what: $\mathrm{ABi}=$ individual basal area of species $\mathrm{s}\left(\mathrm{cm}^{2}\right)$; e TBA $=$ total basal area $\left(\mathrm{cm}^{2}\right)$.

f) Coverage value of the species VCs (\%): VCs = DRs + DoRs; em que: DRs = relative density of species i (\%); e DoRs $=$ relative dominance of species $\mathrm{i}(\%)$.

The frequency of each species was calculated by the ratio of the number of individuals of the species to the total number of individuals in the square multiplied by 100 . To calculate the species diversity index in the total area of the square, the Shannon-Weaver index (H ') was used, according to Coelho (2000), where, $H^{\prime}=-\Sigma$ pi (lnpi), where: $\mathrm{pi}=$ proportion of sample containing individuals of species i.

The qualitative analysis was made using a specific form adapted from Silva Filho et al. (2002), with the following conclusions: stem-glass balance (visual assessment done mainly by changing the crown in function and pruning), general status of the specimen (accomplished by means of concept: great, good, regular, lousy and dead), phytosanity (presence or absence of fungus, bacterium, termite, caterpillar, mite, ant, aphid and cochineal) and presence of association with other organisms (others insects, lichens, epiphytes or parasites).

\section{RESULTS}

It can be observed in Table 1 that 13 botanical families were found, divided into 28 species and 25 genera, in a total of 103 individuals. The most frequent species of Dypsis lutescens H. Wendl., with a frequency of $20.39 \%$, followed by Caesalpinia pluviosa DC., with a frequency of $18.45 \%$, while the others did not exceed $10 \%$ (Table 1 ). 
Table 1. Scientific name, botanical family, the origin (exotic - E or native - N), number of specimen per species (N) and frequency - Fr (\%) of the scheduled species in the Rui Barbosa Square, São José do Rio Preto, São Paulo, Brazil.

\begin{tabular}{|c|c|c|c|c|}
\hline Scientific name & Family & $\mathbf{O}$ & $\mathbf{N}$ & $\operatorname{Fr}(\%)$ \\
\hline Dypsis lutescens $\mathrm{H}$. Wendl. & Arecaceae & $\mathrm{E}$ & 21 & 20.39 \\
\hline Caesalpinia pluviosa DC. & Fabaceae & $\mathrm{N}$ & 19 & 18.45 \\
\hline Tabebuia sp. Gomes ex DC. & Bignoniaceae & $\mathrm{N}$ & 8 & 7.77 \\
\hline Livistonia chinensis (N.J. Jacquin) R. Brown ex Mart. & Arecaceae & $\mathrm{E}$ & 7 & 6.80 \\
\hline Pachira aquatica Aubl. & Bombacaceae & $\mathrm{N}$ & 6 & 5.83 \\
\hline Syagrus oleracea (Mart.) Becc. & Arecaceae & $\mathrm{N}$ & 4 & 3.88 \\
\hline Tabebuia rosealba (Ridl.) Sandwith & Bignoniaceae & $\mathrm{N}$ & 4 & 3.88 \\
\hline Handroanthus impetiginosus (Mart. ex DC.) Mattos & Bignoniaceae & $\mathrm{N}$ & 3 & 2.91 \\
\hline Michelia champaca $\mathrm{L}$. & Magnoliaceae & $\mathrm{E}$ & 3 & 2.91 \\
\hline Roystonea regia (H.B.K.) O.F. Cook & Arecaceae & $\mathrm{E}$ & 3 & 2.91 \\
\hline Calycophyllum spruceanum (Benth.) K.Schum. & Rubiaceae & $\mathrm{N}$ & 3 & 2.91 \\
\hline Myroxylon peruiferum L.f. & Fabaceae & $\mathrm{N}$ & 2 & 1.94 \\
\hline Licania tomentosa (Benth.) Fritsch & Chrysobalanaceae & $\mathrm{N}$ & 2 & 1.94 \\
\hline Triplaris americana $\mathrm{L}$. & Polygonaceae & $\mathrm{N}$ & 2 & 1.94 \\
\hline Terminalia catappa $\mathrm{L}$. & Combretaceae & $\mathrm{E}$ & 2 & 1.94 \\
\hline Tipuana tipu (Benth.) Kuntze, & Fabaceae & $\mathrm{E}$ & 2 & 1.94 \\
\hline Pinus pinea $\mathrm{L}$. & Pinaceae & $\mathrm{E}$ & 1 & 0.97 \\
\hline Annona atemoya Mabb. & Annonaceae & $\mathrm{E}$ & 1 & 0.97 \\
\hline Spondias cytherea Sonnerat Tuss. & Anarcadiaceae & $\mathrm{E}$ & 1 & 0.97 \\
\hline Cassia fistula $\mathrm{L}$. & Fabaceae & $\mathrm{E}$ & 1 & 0.97 \\
\hline Delonix regia (Bojer ex Hook.) Raf. & Fabaceae & $\mathrm{E}$ & 1 & 0.97 \\
\hline Inga vera Willd. & Fabaceae & $\mathrm{N}$ & 1 & 0.97 \\
\hline Handroanthus avellanedae (Lorentz ex Griseb.) Mattos & Bignoniaceae & $\mathrm{N}$ & 1 & 0.97 \\
\hline Phoenix roebelenii O’Brien & Arecaceae & $\mathrm{E}$ & 1 & 0.97 \\
\hline Bauhinia sp. L. & Fabaceae & $\mathrm{N}$ & 1 & 0.97 \\
\hline Caesalpinia echinata Lam. & Fabaceae & $\mathrm{N}$ & 1 & 0.97 \\
\hline Caryota mitis Lour & Arecaceae & $\mathrm{E}$ & 1 & 0.97 \\
\hline Sapindus saponaria L. & Sapindaceae & $\mathrm{N}$ & 1 & 0.97 \\
\hline TOTAL & & & 103 & $100 \%$ \\
\hline
\end{tabular}

When analyzing the origin of the individuals in the square (Table 1), it is observed that $57.28 \%$ are native specimens of the Brazilian national territory; however the species with the highest occurrence is an exotic palm (Dypsis lutescens). The families Arecaceae and Fabaceae presented higher species richness $(35.92 \%$ and $27.18 \%$, respectively) among all the species found in the square.
The phytosociological descriptors evaluated are presented in table 2, the individuals with frequency and density (Dypsis lutescens and Caesalpinia pluviosa) were not the same as those with the highest coverage rates, Delonix regia and Tipuana tipu, since individuals with larger basal areas had a higher dominance value, which raised the coverage value. 
Table 2. Phytosociological parameters of individual trees located at Rui Barbosa Square, São José do Rio Preto, SP. (Frfrequency - \%, AD - absolute density of the species - individual $\mathrm{m}^{-2}$; RD - relative density of the species - \%; AB - basal area of the species $-\mathrm{cm}^{2}$; DoA - absolute dominance of the species - \%; DoR - relative dominance of the species - \%; IVC - coverage amount - \%).

\begin{tabular}{|c|c|c|c|c|c|c|c|}
\hline Scientific name & Fr & AD & RD & $\mathbf{A B}$ & DoA & DoR & IVCs \\
\hline Dypsis lutescens H. Wendl. & 20.39 & 39.60 & 20.39 & 514 & 969 & 0.17 & 969 \\
\hline Caesalpinia pluviosa DC. & 18.45 & 35.83 & 18.45 & 19741 & 37226 & 6.44 & 37233 \\
\hline Tabebuia sp. Gomes ex DC. & 7.77 & 15.09 & 7.77 & 632 & 1193 & 0.21 & 1193 \\
\hline Livistonia chinensis (N.J. Jacquin) R. Brown ex Mart. & 6.80 & 13.20 & 6.80 & 2515 & 4743 & 0.82 & 4744 \\
\hline Pachira aquática Aubl. & 5.83 & 11.31 & 5.83 & 14636 & 27599 & 4.78 & 27604 \\
\hline Syagrus oleracea (Mart.) Becc. & 3.88 & 7.54 & 3.88 & 3105 & 5856 & 1.01 & 5857 \\
\hline Tabebuia rosealba (Ridl.) Sandwith & 3.88 & 7.54 & 3.88 & 4215 & 7948 & 1.38 & 7949 \\
\hline Handroanthus impetiginosus (Mart. ex DC.) Mattos & 2.91 & 5.66 & 2.91 & 14104 & 26597 & 4.60 & 26602 \\
\hline Michelia champaca $\mathrm{L}$. & 2.91 & 5.66 & 2.91 & 1320 & 2490 & 0.43 & 2490 \\
\hline Roystonea regia (H.B.K.) O.F. Cook & 2.91 & 5.66 & 2.91 & 14386 & 27128 & 4.70 & 27132 \\
\hline Calycophyllum spruceanum (Benth.) K.Schum. & 2.91 & 5.66 & 2.91 & 147 & 276 & 0.05 & 276 \\
\hline Myroxylon peruiferum L.f. & 1.94 & 3.77 & 1.94 & 15895 & 29973 & 5.19 & 29978 \\
\hline Licania tomentosa (Benth.) Fritsch & 1.94 & 3.77 & 1.94 & 7855 & 14812 & 2.56 & 14815 \\
\hline Triplaris americana $\mathrm{L}$. & 1.94 & 3.77 & 1.94 & 1402 & 2644 & 0.46 & 2645 \\
\hline Terminalia catappa L. & 1.94 & 3.77 & 1.94 & 2758 & 5200 & 0.90 & 5201 \\
\hline Tipuana tipu (Benth.) Kuntze & 1.94 & 3.77 & 1.94 & 35805 & 67518 & 11.69 & 67530 \\
\hline Pinus pinea $\mathrm{L}$. & 0.97 & 1.89 & 0.97 & 24609 & 46406 & 8.03 & 46414 \\
\hline Annona atemoya Mabb. & 0.97 & 1.89 & 0.97 & 453 & 853 & 0.15 & 853 \\
\hline Spondias cytherea Sonnerat Tuss. & 0.97 & 1.89 & 0.97 & 27763 & 52353 & 9.06 & 52362 \\
\hline Cassia fistula $\mathrm{L}$. & 0.97 & 1.89 & 0.97 & 3740 & 7052 & 1.22 & 7053 \\
\hline Delonix regia (Bojer ex Hook.) Raf. & 0.97 & 1.89 & 0.97 & 66061 & 124572 & 21.56 & 124594 \\
\hline Inga vera Willd. & 0.97 & 1.89 & 0.97 & 2642 & 4983 & 0.86 & 4984 \\
\hline $\begin{array}{l}\text { Handroanthus avellanedae } \\
\text { (Lorentz ex Griseb.) Mattos }\end{array}$ & 0.97 & 1.89 & 0.97 & 19983 & 37683 & 6.52 & 37690 \\
\hline Phoenix roebelenii O'Brien & 0.97 & 1.89 & 0.97 & 1018 & 1920 & 0.33 & 1920 \\
\hline Bauhinia sp. L. & 0.97 & 1.89 & 0.97 & 3319 & 6258 & 1.08 & 6259 \\
\hline Caesalpinia echinata Lam. & 0.97 & 1.89 & 0.97 & 5946 & 11212 & 1.94 & 11213 \\
\hline Caryota mitis Lour & 0.97 & 1.89 & 0.97 & 8578 & 16176 & 2.80 & 16178 \\
\hline Sapindus saponaria L. & 0.97 & 1.89 & 0.97 & 3217 & 6067 & 1.05 & 6068 \\
\hline
\end{tabular}

Rui Barbosa Square presented the Shannon-Weaver index of 2.77 . Only $3.88 \%$ of the individuals had a height equal to or less than $3.5 \mathrm{~m}$. Among the species of larger tree size, the Pinus pinaster stood out with 23.5 meters, followed by the Handroanthus avellanedae with 22 meters of height; only Caesalpinia pluviosa was the one with the highest occurrence with a height of more than 9 meters.

Among the individuals, $72.8 \%$ are in a regular and very poor condition, that is, with numerous injuries, most of which presented trunk and branches damaged by inadequate pruning, breaks or vandalism, where nails and other hanging objects were observed set on the trees. No lesions were found in $4.85 \%$ of the species.

A high number of trees were found with presence of pests and/or pathogens; among the 103 individuals evaluated, $68(66.02 \%)$ had some fungus. It was observed that these fungi were present mainly in lesions caused by inadequate pruning or even breaking of branches, in other cases the openings for these fungi occurred in places where the trees came in contact with some construction. The presence of fungi was observed mainly in Caesalpinia pluviosa specimens (19 plants). In Rui Barbosa Square, mosses, lichens and epiphytes were found in $73.78 \%$ of the inventoried individuals. 


\section{DISCUSSION}

In this study, 13 botanical families were found, divided into 28 species and 25 genera, in a total of 103 individuals. Of these species, the highest occurrence was Dypsis lutescens, with specific density of $20.39 \%$, followed by Caesalpinia pluviosa, with $18.45 \%$, while the others did not exceed $10 \%$. There are few species with a high number of individuals and many with few, with $38.84 \%$ of the total number of specimens being concentrated in only these two species, presenting a very fragile ecological picture.

This fragility is accentuated by the origin of the two most occurring species, Dypsis lutescens is exotic, originating in Madagascar (LORENZI et al., 1996) and Caesalpinia pluviosa, although native to Brazil and well adapted in different situations, occurs in the Mata Atlantic region of Rio de Janeiro, in southern Bahia and large populations in the Pantanal region of Mato Grosso State (LORENZI, 2008), being therefore not native to the region of São José do Rio Preto, São Paulo State.

Analyzing the origin of all arboreal individuals in Rui Barbosa Square, it is observed that $56.31 \%$ are native to the Brazilian national territory; however, according to Lorenzi (2008), only $16.5 \%$ occur naturally in the region, the others are from different ecosystems and regions. The results show the need for interference in this place, seeking to maintain a greater ecological balance for biodiversity.

According to Paiva et al. (2010) from the ecological point of view adaptive and functional, it is technically recommendable the use of native species of the region worked, mainly to guarantee coevolutive and genetic ecological relations, dispersion of propagules (pollen and seeds), involving fauna and flora inside the environment urban and also for the conservation of native genetic material.

The frequencies of the two species that occur most in Praça Rui Barbosa are not in agreement with the one recommended by Milano and Dalcin (2000) suggest that each species should have 10 to $15 \%$ of the total frequency.

Although not recommended, the high frequency of one or two tree species has been observed in several situations in Brazilian cities. Pires et al. (2010) found that in Goiandira, Goias State, Licania tomentosa presented a frequency of $20 \%$. Salvi et al. (2011) in a study in the streets and green tunnels of the city of Porto Alegre, Rio Grande do Sul State, verified that among the green tunnels the homogeneity of the flora is high, with a predominance of few species, such as Jacaranda mimosifolia and Tipuana tipu, which could be compared to an urban "tree monoculture".

The families Arecaceae and Fabaceae presented the highest number of species among those found in Rui Barbosa Square (36\% and 27\%, respectively). Similarly, Romani et al. (2012) also observed a higher number of species of the families Arecaceae (57\%), Fabaceae (38\%) and Bignoniaceae (20\%) in Praça XV de Novembro, Ribeirão Preto, São Paulo State. Gimenes et al. (2011) also observed a higher number of species in the Arecaceae family (60\%), followed by Leguminosae-Caesalpinioideae (51\%) and Bignoniaceae (33\%), as being the most representative.
Analyzing the phytosociological descriptors, it was observed that the individuals with frequency and density (Dypsis lutescens and Caesalpinia pluviosa) were not the same ones that obtained the highest rates of coverage, Delonix regia and Tipuana tipu, since the individuals with larger basal areas had a higher dominance value, which increased the coverage value.

Analyzing the same parameters, Barbosa et al. (2012) observed that the species Spondia tuberosa, Parapiptadenia zehntneri and Ceiba glaziovii, although presenting few individuals, obtained good results in relation to the dominance, due to having large diameters, thus generating higher basal values.

Despite the ecological fragility observed in Rui Barbosa Square, the Shannon-Weaver index found was 2.77, which can be considered a great floristic diversity. The value of this index varies from 0 to 3.5 and rarely reaches 4.5 , values close to 1 indicate environmental stress related to polluted areas or even monoculture (BUOSI et al., 2010). This index is higher than another observed in a caatinga area in Arcoverde, PE, with 2.05 (BARBOSA et al., 2012) and lower than that found by Romani et al. (2012) in the four-square central area of Ribeirão Preto, São Paulo State, whose index was 3.37.

Regarding the height of the trees in Rui Barbosa Square, only $3.88 \%$ of the individuals presented height equal to or less than $3.5 \mathrm{~m}$, evidencing that the plants were adult or well developed, probably due to the planting of quality seedlings and use of species that are well adapted to local conditions. Among the species of larger tree size, the Pinus pinaster stood out with $23.5 \mathrm{~m}$, followed by the Handroanthus avellanedae with $22 \mathrm{~m}$ of height; only Caesalpinia pluviosa was the one with the highest occurrence with a height of more than $9 \mathrm{~m}$.

Similarly, in a study carried out in XV de Novembro Square, one of the main ones of Ribeirão Preto, São Paulo State, Romani et al. (2012) observed that $4.97 \%$ of individuals had a height of $3.5 \mathrm{~m}$ or less; this square is also old and the result showed that most of the plants are well developed, in the adult stage.

The majority $(72.8 \%)$ of the trees present in Rui Barbosa Square are in a regular or very poor condition, that is, with numerous lesions, many of which have trunk and branches damaged by inadequate pruning, breaks or vandalism, where they observed nails and other objects hung or fixed in the trees. During the survey, no lesions were found in about $4.85 \%$ of the subjects. In the analysis performed by Romani et al. (2012) in XV de Novembro Square, in Ribeirão Preto, São Paulo State, the proportion of trees in a regular or poor state was lower (58.4\%).

Trees must be prepared to protect themselves against the action of organisms programmed to degrade plant biomass. This protection process is called the compartmentalization of injury, and aims to create barriers inside the trunk to prevent fungal growth degraders (SEITZ, 1996). Often this can not be done by itself. So, proper pruning and aiding of products for quick healing are needed.

A high number of trees were found with presence of pests and / or pathogens; among the 103 individuals evaluated, $68(66.02 \%)$ had some fungus symptoms. It was 
observed that these fungi were present mainly in lesions caused by inadequate pruning or even breaking of branches, in other cases openings for these fungi occurred in places where the trees were in contact with some construction. The presence of fungi was observed mainly in Caesalpinia pluviosa specimens (19 plants).

It is worth mentioning that the fungi present in the trees are usually related to the injuries that allow the installation of these organisms; being many caused by inadequate pruning or broken branches. It should be noted, however, that the method of analysis was visual, and the trunk was not prospected. It was also observed that some trees (33\%) are attacked by termites, ants and also by a parasite called Ficus doliaria.

According to Rossetti et al. (2010), the biggest problem that compromises the health of trees in the urban environment is termite infestation, and this pest is observed in $8.33 \%$ of the total number of trees inventoried in two São Paulo neighborhoods in Ipiranga. Romani et al. (2012) also reported that there is this problem in XV de Novembro Square, in Ribeirão Preto, São Paulo State; among the 161 individuals evaluated, $18.6 \%$ presented termite attack of the genus Nasutitermes, mainly in Caesalpinia pluviosa species.

The presence of mosses, lichens and epiphytes was verified in Rui Barbosa Square in $73.78 \%$ of the individuals inventoried. They are strong indications of good climate and low air pollution (SAMPAIO and DE ANGELIS, 2008). These authors, in a survey in the city of Maringá, Paraná State, found moss, lichens and epiphytes in $70 \%$ of all trees, considered by them as a good indicator of quality, similar to that observed at Rui Barbosa Square in São José do Rio Preto, São Paulo State.

\section{CONCLUSIONS}

Rui Barbosa Square, in São José do Rio Preto, São Paulo State, Brazil is composed of 15 botanical families, composed of 25 genera and 28 species, in a total of 103 individuals, where the most frequent species was Dypsis lutescens (20.39\%).

Rui Barbosa Square presents great floristic diversity (Shannon-Weaver index was 2.77).

\section{AUTHORS CONTRIBUTIONS}

C.J.F. D0000-0001-5027-6732: conception and design of the research, obtaining data, analyze and interpretation of data, statistical analysis, write and critically analyses of manuscript. M.V.F. 0000-0002-5940-8196: analyze and interpretation of data, write and critically analyses ofmanuscript. R.G. D0000-0002-6610-3761 : analyze and interpretation of data, statistical analysis, write and critically analyses of manuscript. S.T.S.P. (D0000-0003-0424-489x: analyze and interpretation of data and statistical analysis of manuscript. K.F.L.P. D0000-0001-9983-2402: conception and design of the research, obtaining data, analyze and interpretation of data, statistical analysis, write and critically analyses of manuscript.

\section{REFERENCES}

APG - ANGIOSPERM PHYLOGENY GROUP. An ordinal classification for the families of flowering plants. Annals of the Missouri Botanical Garden, v.85, n.4, p.531-553, 1998. DOI: $10.2307 / 2992015$

BARBOSA, M.D.; MARANGON, L.C.; FELICIANO, A.L.P.; FREIRE, F.J.; DUARTE, G.M.T. Florística e fitossociologia de espécies arbóreas e arbustivas em uma área de caatinga em Arcoverde, PE, Brasil. Revista Árvore, v.36, n.5, p.851-858, 2012. DOI: http://dx.doi.org/10.1590/ S0100-67622012000500007

BATISTA, G.S.; BORELLA, H.D.; GIMENES, R.; ROMANI, G.N.; PIVETTA, K.F.L. Análise qualiquantitativa da vegetação e dos elementos arquitetônicos da praça Dom Assis, Jaboticabal, São Paulo. Revista Brasileira de Horticultura Ornamental, v.19, n.1, p.718, 2013. DOI: https://doi.org/10.14295/rbho.v19i1.423

BOLUND, P.; HUNHAMMAR, S. Ecosystem services in urban areas. Ecological Economics, v.29, p.293-301, 1999.

BUOSI, C.; FRONTALINI, F.; PELO, S.; CHERCHI, A.; COCCIONI, R; BUCCI, C. Foraminiferal proxies for environmental monitoring in the polluted lagoon of Santa Gilla (Cagliari, Italy). Present Environmentand Sustainable Development, v.4, n.4, p.91-104, 2010.

COELHO, R.M.P. Fundamentos em ecologia. Porto Alegre: Artes Médicas Sul, 2000. 247p.

EMBRAPA. Empresa Brasileira de Pesquisa Agropecuária. Disponível em: <http://www.cnpf.embrapa.br/pesquisa/ efb/clima.htm $>$ Acessed in: november 3rd 2015.

GIMENES, R.; ROMANI, G.N.; BATISTA, G.S.; PIVETTA, K.F.L. Interpretação do uso, do mobiliário e da arborização da Praça Sete de Setembro, Ribeirão Preto, SP. Revista da Sociedade Brasileira de Arborização Urbana. v.6, n.3, p.22-42, 2011.

GONÇALVES, W.B; CORAL, D.J.; SIQUEIRA, M.V.B.M. Caracterização da arborização urbana no bairro centro do município de Ibitinga/SP. Revista da Sociedade Brasileira de Arborização Urbana, v.12, n.3, p.66-79, 2017.

IBGE. Instituto Brasileiro de Geografia e Estatística. Disponível em: <http://www.cidades.ibge.gov.br/xtras/ perfil.php?lang=\&codmun=354980\&search=sao-paulo|saojose-do-rio-preto $>$. Acessed in: august 10th 2015.

KRAMER, J.A.; KRUPEK, R.A. Caracterização florística e ecológica da arborização de praças públicas do município de Guarapuava, PR. Revista Árvore, v.36, n.4, p.647-658, 2012. DOI: http://dx.doi.org/10.1590/S0100-67622012000400007 
LIMA NETO, E.M.; RESENDE, W.X.; SENA, M.G.D.; MELO e SOUZA, R. Análise das áreas verdes das praças do bairro centro e principais avenidas de Aracaju - SE. Revista da Sociedade Brasileira de Arborização Urbana, v.2, n.1, p.17-33, 2007.

LORENZI, H. Árvores Brasileiras: manual de identificação e cultivo de plantas arbóreas nativas do Brasil. 5.ed. v.1. Nova Odessa: Instituto Plantarum, 2008. 384p.

LORENZI, H. Árvores Brasileiras: manual de identificação e cultivo de plantas arbóreas nativas do Brasil. 3.ed. v.2. Nova Odessa: Instituto Plantarum, 2009. 384p.

LORENZI, H.; NOBLICK, L.R.; KAHN, F.; FERREIRA, E. Flora Brasileira: Arecaceae (Palmeiras). Nova Odessa: Instituto Plantarum, 2010. 384p.

LORENZI, H.; SOUZA, H.M.; MEDEIROS-COSTA, J.T.; CERQUEIRA, L.S.C.; BEHR, N. Palmeiras no Brasil: nativas e exóticas. Nova Odessa: Instituto Plantarum, 1996. 303p.

LORENZI, H.; SOUZA, H.M.de; TORRES, M.A.V.; BACHER, L.B. Árvores exóticas no Brasil: madeiras, ornamentais e aromáticas. 1.ed. v.1. Nova Odessa: Instituto Plantarum, 2003. 368p.

MILANO, M.; DALCIN, E. Arborização de vias públicas. Rio de Janeiro: LIGHT, 2000. 226p.

PAIVA, V.A.; LIMA, A.B.M.; CARVALHO, A.; JUNIOR, A.M.; GOMES, A.; MELO, C.S.; FARIAS, C.O.; REIS, C.; BEZERRA, C.; JUNIOR, E.A.S.; MACEDO, E.; LIMA, E.S.; SOBRINHO, F.; SILVA, F.M.; BONFIM, J.C.; JUNIOR, L.S.; CORREA, M.; DUMONT, M.L.; ISAAC, M.A.; PANTOJA, N.V.; DAVILA, R.M.; GABRIEL, R.; SILVA, R.A.; CUNHA, R.M.; OLIVEIRA, R.S.; DIAS, R.; NICHELI, S.P.; COSTA, S.; SOUZA, T.C.; PEREIRA, T.F.; CASTELO, Z.; FERRARI, Z.S. Inventário e diagnóstico da arborização urbana viária de Rio Branco, AC. Revista da Sociedade Brasileira de Arborização Urbana, v.5, n.1, p.144-159, 2010.

PIRES, N.A.M.T.; MELO, M.S.; OLIVEIRA, D.E.; XAVIER-SANTOS, S. A arborização urbana no município de Goiandira/GO - Caracterização quali-quantitativa e proposta de manejo. Revista da Sociedade Brasileira de Arborização Urbana, v.5, n.3, p.185-205, 2010.

RODERJAN, C.V.; BARDDAL, M.L. Arborização das ruas de Curitiba-PR: guia prático para identificação das espécies. Curitiba: FUPEF, 1998. 14p.
RODRIGUES, R.R. Métodos fitossociológicos mais usados. São Paulo: Casa da Agricultura, 1988. Separata.

ROMANI, G.N.; GIMENES, R.; SILVA, M.T.; PIVETTA, K.F.L.; BATISTA, G.S. Análise quali-quantitativa da arborização na Praça XV de Novembro em Ribeirão Preto SP, Brasil. Revista Árvore, v.36, n.3, p.479-487, 2012. DOI: http://dx.doi.org/10.1590/S0100-67622012000300010

ROSSETTI, A.I.N.; TAVARES, A.R.; PELLEGRINO, P.R.M. Inventário arbóreo em dois bairros paulistanos, Jardim da Saúde e Vila Vera, localizados na subprefeitura de Ipiranga. Revista Árvore, v.34, n.5, p.889-898, 2010. DOI: http://dx.doi.org/10.1590/S0100-67622010000500014

SALVI, L.T.; HARDT, L.P.A.; ROVEDDER, C.E.; FONTANA, C.S. Arborização ao longo de ruas túneis verdes - em Porto Alegre, RS, Brasil: Avaliação quantitativa e qualitativa. Revista Árvore, v.35, n.2, p.233-243, 2011. DOI: http://dx.doi.org/10.1590/S010067622011000200008 .

SAMPAIO, A.C.F.; DE ANGELIS, B.L.D. Inventário e análise da arborização de vias públicas de Maringá PR. Revista da Sociedade Brasileira de Arborização Urbana, v.3, n.1, p.37-57, 2008.

SEITZ, R.A. A poda de árvores urbanas. In: $1^{\circ}$ Curso em Treinamento sobre Poda em Espécies Arbóreas Florestais e de Arborização Urbana. Piracicaba: IPEF/USP, 1996.

SHAMS, J.C.A.; GIACOMELI, D.C.; SUCOMINE, N.M. Emprego da arborização na melhoria do conforto térmico nos espaços livres públicos. Revista da Sociedade Brasileira de Arborização Urbana, v.4, n.4, p.1-16, 2009.

SILVA FILHO, D.F.; BORTOLETO, S. Uso de indicadores de diversidade na definição de plano de manejo da arborização viária de Águas de São Pedro-SP. Revista Árvore, v.29, n.6, p.973-982, 2005. DOI: http://dx.doi. org/10.1590/S0100-67622005000600017

SILVA FILHO, D.F.; PIZETTA, P.U.C.; ALMEIDA, J.B.S.A.; PIVETTA, K.F.L.; FERRAUDO, A.S. Banco de dados relacional para cadastro, avaliação e manejo da arborização em vias públicas. Revista Árvore, v.26, n.5, p.629-642, 2002.

SOUZA, V.C.; LORENZI, H. Botânica sistemática: guia ilustrado para identificação das famílias de Angiospermas da flora brasileira, baseado em APG II. Nova Odessa: Instituto Plantarum de Estudos da Flora Ltda, 2005. 640p. 